vasculogenesis during first trimester of pregnancy", Ultrasound in Obstetrics \& Gynecology, 41 (5), pp. 538-544.

5. Bodnar L. M., Ness R. B., Markovic N., et al. (2005), "The risk of preeclampsia rises with increasing prepregnancy body mass index", Annals of epidemiology, 15 (7), pp. 475-482.

6. Sohlberg S., Stephansson O., Cnattingius S., et al. (2012), "Maternal body mass index, height, and risks of preeclampsia", American journal of hypertension, 25 (1), pp. 120-125.

7. Bartsch E., Medcalf K. E., Park A. L., et al.
(2016), "Clinical risk factors for pre-eclampsia determined in early pregnancy: systematic review and meta- analysis of large cohort studies", Bmj, 353.

8. Organization W. H. (1995), "Physical status: The use of and interpretation of anthropometry, Report of a WHO Expert Committee".

9. Velauthar L., Plana M., Kalidindi M., et al. (2014), "First-trimester uterine artery Doppler and adverse pregnancy outcome: a meta-analysis involving 55974 women", Ultrasound in Obstetrics \& Gynecology, 43 (5), pp. 500-507.

\title{
HOAI TỬ XƯO'NG HÀM DO BISPHOSPHONATE: BÁO CÁO HAI TRƯờNG HỢP LÂM SÀNG
}

\author{
Trần Thu Giang ${ }^{1,2}$, Đặng Triệu Hùng ${ }^{1,2}$, Phạm Hoài Thu ${ }^{1,2}$
}

\section{TÓM TẮT}

Hoai tử xương hàm là môtt trong những biến chứng của điểu trị loãng xương bằng thuốc bisphosphonate có thể để lai hâu quả nghiêm trong cho bệnh nhân. Tuy nhiên do đây là biến chứng hiếm gặp, lâm sàng không điển hình nên đôi khi bị bỏ sót chẩn đoán ở giai đoạn đâu dẫn tới tình trang tổn thương xương hàm nặng và phải can thiệp phâuu thuật. Tại bệnh viện Đại học Y Hà Nội chúng tồi gặp hai trường hợp bệnh nhân được chẩn đoán hoại tử xương hàm dưới do dùng bisphosphonate đường uống điều trị loãng xương, cả hai bệnh nhân đã được điều trị phẫu thuật loại bỏ xương chết và cho kết quả đáp ứng với điều trị.

Tư khóa: hoại tử xương hàm, bisphosphonate, loãng xương

\section{SUMMARY \\ BISPHOSPHONATE-RELATED OSTEONECROSIS OF THE JAW: A TWO- CASE REPORT}

Osteonecrosis of the jaw is a complication of osteoporosis treatment by bisphosphonate, which can cause serious issues for patients. This is a rare complication with unspecific symptoms and signs, and so makes it difficult to diagnose at early stage. Thus, leads to severe jaw destruction and needs to operate. In Hanoi Medical University hospital, we had two patients who diagnosed with oral bisphosphonaterelated osteonecrosis of the jaw. Both patients were under operation to remove death bone and brought good results.

Keywords: osteonecrosis of the jaw, bisphosphonate, osteoporosis

\footnotetext{
${ }^{1}$ Trường Đại học Y Hà Nội

${ }^{2}$ Bênh viên Đai họ Y Hà Nôi

Chịu trách nhiệm chính:

Email: trthugiang@gmail.com

Ngày nhận bài: 21.9.2021

Ngày phản biên khoa họ: 17.11.2021

Ngày duyệt bài: 24.11.2021
}

\section{I. ĐĂT VẤN ĐỀ}

Loãng xương là bệnh lý đặc trưng bởi sự thay đổi sức mạnh xương, bệnh thường gặp với biến chứng gãy xương gây hậu quả nặng nề. Tại Việt Nam có khoảng 2,5 triệu người bị loãng xương và trên 150.000 trường hợp bị gãy xương do loãng xương. ${ }^{1}$ Bisphosphonate là thuốc được lựa chọn đầu tay trong dự phòng và điều trị loãng xương do hiệu quả cao và dung nạp tốt. Những tác dụng phụ có thể gặp là viêm thực quản, gãy xương đùi không điển hình và hoại tử xương hàm. Trường hợp đầu tiên hoại tử xương hàm do bisphosphonate được Marx cổng bố năm 2003, ${ }^{2}$ sau đó đã có một số trường hợp được mô tả trong và ngoài nước, tỷ lệ gặp từ $0,001 \%$ tới $0,01 \%{ }^{3}$ Tuy nhiên do tuổi thọ người dân ngày càng tăng, số lượng bệnh nhân được chẩn đoán loãng xương cũng ngày càng nhiều. Từ đó dẫn tới tăng số lượng bệnh nhân được điều trị với bisphosphonate cũng như gặp phải biến chứng này. Biến chứng hoại tử xương hàm là một biến chứng nặng và khó điều trị, có thể gầy gãy xương hàm bệnh lý.

\section{BÁO CÁO TRƯỜNG HợP LÂM SÀNG}

1. Trường hợp thứ nhất. Bệnh nhân nữ 77 tuổi vào viện vì đau vùng xương hàm dưới, lộ xương trong miệng. Bệnh nhân có tiền sử loãng xương điều trị alendronate $70 \mathrm{mg} /$ tuần trong 10 năm, không thường xuyên. Bệnh nhân không có tiên sử xạ trị vùng đầu cổ. Bệnh nhân sau nhố răng cách đầy 1 năm, ổ răng không lành, xuất hiện chảy mủ tại huyệt ổ răng, đi khám và điều trị nha khoa bằng phương pháp nạo ổ viêm và dùng thuốc kháng sinh nhiều đợt không cải thiện.

Khám lâm sàng niêm mạc lợi vùng hàm dưới bên phải có điểm chảy mủ, lộ xương màu vàng, 
nhiều mảng bám và hôi. Ấn đau nhe có mủ chảy ra. Mất răng 45,46,47, răng 48 nghiêng gần lung lay độ 1.

Phim $X$ quang panorama có hình ảnh xương chết tương ứng vị trí xương ổ răng hàm dưới phải. Mật độ xương: T-score cổ xương đùi trái/ cổ xương đùi phải/cột sống thắt lưng: $-3,2 /-3,0 /-$ 3,1 . Kết quả sinh thiết: mô xương có nhiêu vùng thoái hóa hoại tử với một số mảnh xương chết. Mô liên kết sung huyết xâm nhập bạch cầu trung tính.

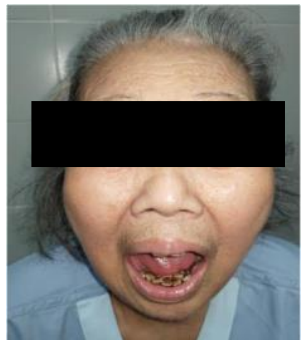

Hinh 1a.

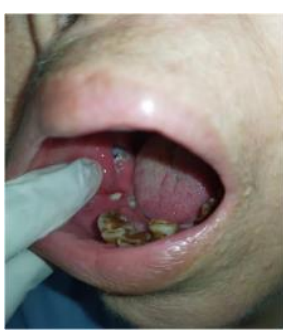

Hinh $1 b$.
Hình 1a, 1b: Bênh nhân Pham Thị H. 77 tuổi, MHS 2104011150 bệnh viện Đại học Y Hà Nôi.

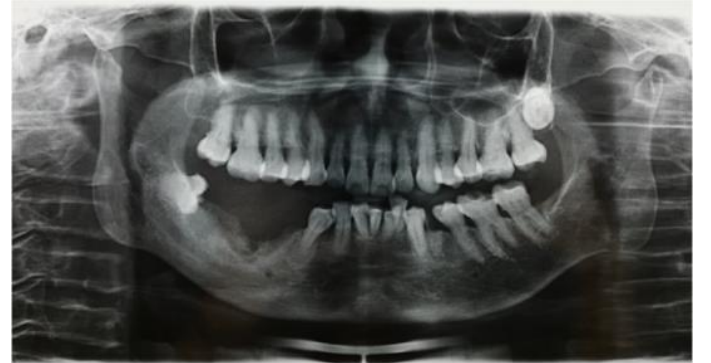

Hình 2. Phim panorama có hình ảnh đám xương hoại tử hàm dưới phải

(*Nguồn bệnh nhân Phạm Thị H. 77 tuổi MHS 2104011150 bệnh viện Đại học Y Hà Nội)

Chẩn đoán hoại tử xương hàm dưới phải liên quan tới dùng bisphosphonate.

Điều trị: Phẫu thuật nạo vét rộng vùng xương chết đến vị trí xướng lành, nhổ răng 48. Cefoperazone $1 \mathrm{~g} \times 2$ lọ truyền tĩnh mạch kết hợp Metronidazol $500 \mathrm{mg} \times 2$ chai truyền tĩnh mạch.

2. Trường hợp thứ hai. Bệnh nhân nữ 59 tuổi. Bệnh nhân có tiền sử phẫu thuật cắt u lợi vùng cửa hàm dưới tháng 12/2020. Sau mổ bệnh nhân sưng đau hàm dưới, chảy mủ, được tiến hành phẫu thuật nạo viêm tháng 5/2021. Mười ngày trước vào viện bệnh nhân vẫn còn sưng đau, chảy mủ vùng răng cửa hàm dưới, đi khám phòng khám tư điều trị kháng sinh không đỡ nên vào viện. Tiền sử: đái tháo đường 3 năm. Loãng xương 3 năm điều trị Ibandronate $150 \mathrm{mg} /$ tuần.

Khám: Lợi vùng hàm dưới sưng nề, ấn đau, vuốt chảy mủ vàng loãng.

Xét nghiệm HbA1c 7,3\%

Đo mật độ xương T-score cổ xương đùi trái/ cổ xương đùi phải/ cột sống thắt lưng :-1/-1,1/2,4. Giải phẫu bệnh xương hàm dưới: mô xương thoái hóa hoại tử.

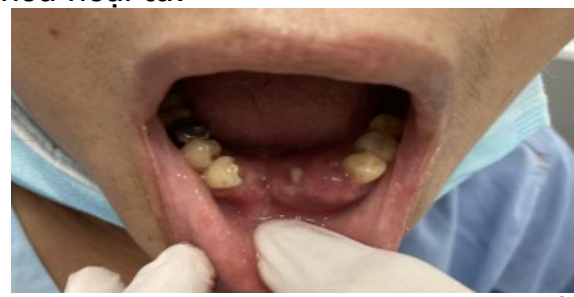

Hình 3: bệnh nhân Hứa Thị X. 59 tuổi, MHS 2106233631 bênh viện Đại học Y Hà Nôii.

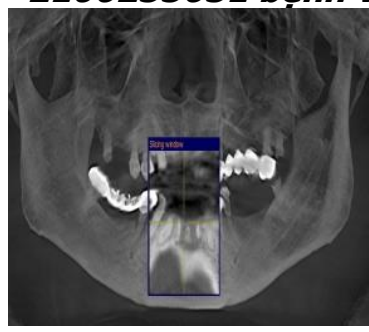

Hinh 4a

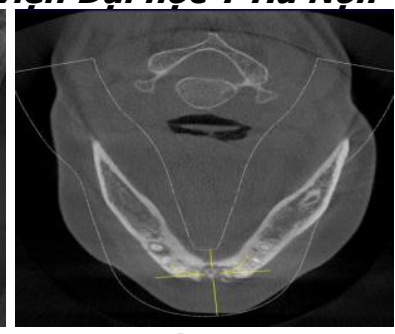

Hinh 4b
Hình 4a,b: Phim Conebeam CT có hình ảnh hoai tử xương hàm dưới

(Nguồn: bểnh nhân Hứa Thị X. 59 tuổi MHS 2106233631 bệnh viện Đại học Y Hà Nội).

Chẩn đoán hoại tử xương hàm dưới phải liên quan tới dùng bisphosphonate.

Điều trị: Phẫu thuật lấy bỏ xương chết, nạo ổ viêm đến vị trí xương lành. Clindamycin $600 \mathrm{mg} x$ 2 lọ/ngày truyền tĩnh mạch kết hợp Metronidazol $500 \mathrm{mg} \times 2$ lọ/ngày truyền tĩnh mạch.

\section{BÀN LUÂN}

Loãng xương là bệnh lý mạn tính có xu hướng tăng theo tuổi thọ dân số ngày càng cao. Bệnh làm tăng nguy cớ gãy xương nếu không được điều trị. Chỉ định điều trị loãng xương cho phụ nữ mãn kinh và nam giới trên 50 tuổi theo hiệp hội loãng xương quốc gia Hoa Kỳ là: tiền sử gãy cổ xương đùi hoặc gãy thân đốt sống; Tscore cột sống thắt lưng, cổ xương đùi $\leq-2.5$ (đo bằng phương pháp DXA); $-1 \leq \mathrm{T}$-score cột sống thắt lưng, cổ xương đùi $<-2.5$ và nguy cơ gãy cổ xương đùi 10 năm $\geq 3 \%$ hoặc nguy cơ gãy xương lớn do loãng xương 10 năm $\geq 20 \%{ }^{4}$

Bisphosphonate là một nhóm thuốc quan trọng trong điều trị loãng xương, có tác dụng chống hủy xương, làm chậm chu chuyển xương. Có hai nhóm thuốc bisphosphonate là nhóm không chứa nitrogen (nhóm thuốc thế hệ đầu) và nhóm bisphosphonate chứa nitrogen. Thuốc 
có thời gian bán thải kéo dài, tích tụ nhiều ở những xương có chuyển hóa cao như xương hàm. Ngoài ra, xương hàm còn có những đặc điểm riêng biệt như sự phát triển xương nhờ quá trình canxi hóa nội màng, mô xương giàu collagen, hủy cốt bào nhạy cảm với bisphosphonate ${ }^{5}$ khiến tăng nguy cơ bị hoại tử. Cơ chế gây hoại tử xương hàm được giả định do sự phối hợp của quá trình tổn thương sau sang chấn như nhổ răng, phẫu thuật kết hợp với tình trang nhiễm trùng tại chỗ làm tăng hủy cốt bào và độc tính của bisphosphonate lên xương.

Yếu tố nguy cơ của hoại tử xương hàm bao gồm: liên quan đến thuốc như hiệu lực của bisphophonate (thuốc dùng đường tĩnh mạch, nhóm bisphosphonate có chứa nitrogen, ${ }^{6}$ liều cao trong điều trị ung thư và thời gian kéo dài $>3$ năm), sử dụng corticosteroid, vệ sinh răng miệng kém, đái tháo đường. Những yếu tố tại chỗ có thể khởi phát hoại tử xương hàm như: chấn thương do phẫu thuật can thiệp răng hàm mặt, viêm nhiễm mô nha chu.

Hai bênh nhân của chúng tôi đều đủ tiêu chuẩn để chẩn đoán xác định theo hội phẫu thuật răng hàm mặt Hoa Kỳ (AAOMS): lộ xương không liền kéo dài trên 8 tuần, tiền sử dùng bisphosphonate, không có tiền sử xạ trị vùng đầu cổ hoặc ung thư di căn xương hàm. Bệnh nhân thứ hai có đái tháo đường, cũng là yếu tố nguy cơ của hoại tử xương hàm. Triệu chứng xuất hiện sau can thiệp vùng hàm mặt và hai bênh nhân đều không được chẩn đoán là hoai tử xương hàm ở những lần khám đâuu tiên. Tại thời điểm nhập viện, tổn thương được đánh giá ở giai đoạn 3 theo phân loại của AAOMS: hoại tử thông tới xương, nhiễm trùng và hoại tử lan ra khỏi xương ổ răng. ${ }^{7}$ Do mức độ tổn thương nặng, cả hai bệnh nhân đều đòi hỏi phải được phẫu thuật loại bỏ xương chết, nạo viêm kết hợp với điều trị kháng sinh và súc miệng với dung dịch chlorhexidine.

Hai bệnh nhân đều đang được tạm dừng điều trị bisphosphonate, bệnh nhân thứ 2 cũng đã dùng thuốc được 3 năm, mật độ xương cải thiện, T-score > $-2,5$, tỷ lệ gãy xương chính là $4,8 \%$; tỷ lệ gãy xương đùi là $0,4 \%$ nên có thể dừng bisphosphonat. Tuy nhiên bệnh nhân thứ nhất dù điêu trị bisphosphonate trong 10 năm nhưng điều trị không đều, T-score cổ xương đùi trái/ cổ xương đùi phải/ cột sống thắt lưng: $-3,2 /-3,0 /-$ 3,1 còn thấp và có nguy cơ gãy xương do loãng xương. Do đó sau khi tổn thương lành bệnh nhân cần được xem xét chỉ định tiếp tục điêu trị loãng xương. Việc dừng bisphosphonate với bệnh nhân hoại tử xương hàm là điểm vẫn còn nhiều tranh luận do tỷ lệ bệnh thấp nên hiện tại chưa có đủ bằng chứng lâm sàng để hướng dấn điều trị. Nhiều ý kiến cho rằng việc dừng thuốc không loại trừ hoàn toàn nguy cơ hoại tử xương hàm bởi bisphosphonate vẫn còn tồn tại ở xương trong nhiêuu năm. Thêm vào đó việc dừng thuốc có thể làm tăng biến chứng gãy xương do loãng xương. Hội nha khoa Hoa Kỳ (ADA) cũng nhấn mạnh đây là một quyết định cần được cá nhân hóa, cân nhắc giữa lợi ích và nguy cơ của việc dừng thuốc trên từng trường hợp cụ thể. 8

Do nguy cơ hoại tử xương hàm liên quan tới thời gian dùng thuốc nên cần cân nhắc thời gian có thể dừng thuốc. Hiệp hội nghiên cứu về xương và khoáng chất Hoa Kỳ khuyến cáo thời gian nghỉ thuốc bisphosphonate ("drug holiday") là sau 5 năm với bệnh nhân dùng bisphosphonate đường uống và 3 năm với bệnh nhân dùng đường truyền nếu bệnh nhân khổng có yếu tố nguy cơ cao của gãy xương. ${ }^{9}$ Điểm mấu chốt để dự phòng hoạt tử xương hàm là kiểm soát các yếu tố nguy cơ có thể thay đổi được bao gồm đái tháo đường, hút thuốc, bệnh nha chu. Bệnh nhân cần giữ vệ sinh răng miệng và điêu trị nhiếm trùng tại chố nếu có. Khám theo dõi răng hàm mặt định kỳ mỗi 6 tháng trong thời gian dùng bisphosphonate. Trong trường hợp bệnh nhân cần làm phẫu thuật răng hàm mặt, AAOMS gợi ý nên dừng bisphosphonate 3 tháng trước và sau phẫu thuật.7

\section{KẾT LUÂ̂N}

Hai trường hợp bệnh nhân hoại tử xương hàm sau dùng bisphosphonate kéo dài là một ví dụ điển hình của bệnh. Hoại tử xương hàm do bisphosphonate tuy hiếm gặp nhưng là biến chứng nghiêm trọng. Do đó, trước khi bắt đầu điều trị, bệnh nhân cần được khám răng hàm mặt để phát hiện các yếu tố nguy cơ tại chỗ. Việc dự phòng ở bệnh nhân điểu trị bisphosphonate là khía cạnh rất quan trọng, cần khám răng hàm mặt định kỳ loại trừ các yếu tố nguy cơ, cân nhắc khả năng dừng thuốc trước khi làm các thủ thuật can thiệp răng hàm mặt. Tuy nhiên, điều trị loãng xương vẫn đem lại lợi ích đáng kể hơn so với tỷ lệ nhỏ biến chứng hoại tử xương hàm.

\section{TÀI LIÊU THAM KHẢO}

1. Nguyễn Thị Thanh Hương, Phạm Thị Minh Đức. Phát triển một mô hình tiên lượng loãng xương cho phụ nữ Việt Nam. Thời sự $Y$ học. 2007;15:7-13.

2. Marx RE. Pamidronate (Aredia) and zoledronate (Zometa) induced avascular 
necrosis of the jaws: a growing epidemic. Journal of Oral and Maxillofacial Surgery. 2003;61(9):1115-1117. doi:10.1016/S02782391(03)00720-1

3. Khan AA, Morrison A, Hanley DA, et al. Diagnosis and management of osteonecrosis of the jaw: a systematic review and international consensus. J Bone Miner Res. 2015;30(1):3-23. doi:10.1002/jbmr.2405

4. Cosman F, de Beur SJ, LeBoff MS, et al. Clinician's Guide to Prevention and Treatment of Osteoporosis. Osteoporos Int. 2014;25(10):23592381. doi:10.1007/s00198-014-2794-2

5. Abe T, Sato T, Kokabu S, et al. Zoledronic acid increases the circulating soluble RANKL level in mice, with a further increase in lymphocytederived soluble RANKL in zoledronic acid- and glucocorticoid-treated mice stimulated with bacterial lipopolysaccharide. Cytokine. 2016;83:17. doi:10.1016/j.cyto.2016.03.012

6. Yamazaki T, Yamori $M$, Yamamoto $K$, et al. Risk of osteomyelitis of the jaw induced by oral bisphosphonates in patients taking medications for osteoporosis: A hospital-based cohort study in Japan. Bone. 2012;51(5):882-887. doi:10.1016/j.bone.2012.08.115

7. Ruggiero SL, Dodson TB, Fantasia J, et al. American Association of Oral and Maxillofacial Surgeons Position Paper on Medication-Related Osteonecrosis of the Jaw-2014 Update. Journal of Oral and Maxillofacial Surgery. 2014;72(10):19381956. doi:10.1016/j.joms.2014.04.031

8. Hellstein JW, Adler RA. Managing the care of patients receiving antiresorptive therapy for prevention and treatment of osteoporosis. Recommendations from the American Dental Association Council on Scientific Affairs.2011.

9. Adler RA, El-Hajj Fuleihan G, Bauer DC, et al. Managing Osteoporosis in Patients on Long-Term Bisphosphonate Treatment: Report of a Task Force of the American Society for Bone and Mineral Research. J Bone Miner Res. 2016;31(1):16-35. doi:10.1002/jbmr.2708

\section{KẾT QUẢ SớM PHẪU THUÂT NộI SOI TUYẾN GIÁP QUA TIỀN ĐİNH MIÊNG TRONG ĐIỀU TRI UNG THƯ TUYẾN GIÁP THỂ NHÚ TẠI BỆNH VIỆN K}

\section{TÓM TẮT}

Tổng quan: Phẫu thuật nội soi cắt tuyến giáp qua tiên đình miệng (TOETVA) là kỹ thuật cắt tuyến giáp mới và ngày càng được áp dụng rộng rãi trong điều trị ung thư tuyến giáp trên thế giới. Tuy nhiên ở Việt Nam còn rất ít báo cáo về kết quả điêu trị ung thư tuyến giáp bằng cách tiếp cận này. Đối tượng và phương pháp nghiên cứu: Gồm 30 bệnh nhẩn được chẩn đoán ung thư tuyến giáp được phẫu thuật nội soi bằng phương pháp TOETVA tại Bệnh viện $\mathrm{K}$ từ tháng $5 / 2020$ đến tháng 5/2021. Kết quả: Đô tuổi trung bình là $29,3 \pm 7,4$. Tất cả bệnh nhân đều là nữ giới. U bên phải chiếm $56,7 \%$, bên trái chiếm 43,3\%. 26 BN cắt thuỳ, eo và vét hạch nhóm 6 với thời gian mổ trung bình là 105,5 phút. Chỉ có $4 \mathrm{BN}$ cắt toàn bộ tuyến giáp và vét hạch nhóm 6 hai bên với thời gian mổ trung bình là 140,5 phút. Các biến chứng ít gặp và đa số là tạm thời, hồi phục sau 3 tháng. Tất cả bệnh nhân đều hài lòng về kểt quả thẩm mĩ. Kết luận: TOETVA là một phương pháp an toàn, hiệu quả, đạt kết quả thẩm mĩ tối ưu và nên được áp dưng rộng rã̃i cho nhóm bệnh nhân phù hợp trên thực hành lâmm sàng.

Tư khoá: Toetva, phấu thuật nội soi, nội soi tuyến giáp, tiền đình miệng.

\footnotetext{
${ }^{1}$ Ngoại đầu cổ, Bệnh viện K

2 Trường Đai hoc Y Hà Nôi

Chịu trách nhiệm chính: Ngô Quốc Duy

Email: Duyyhn@gmail.com

Ngày nhận bài: 14.9.2021

Ngày phản biên khoa hoc: 15.11.2021

Ngày duyệt bài: 22.11.2021
}

Ngô Quốc Duy ${ }^{1,2}$, Ngô Xuân Quý ${ }^{1}$

\section{SUMMARY}

EARLY OUTCOMES OF TRANSORAL

\section{ENDOSCOPIC THYROIDECTOMY VESTIBULAR APPROACH IN MANAGEMENT OF PATIENTS \\ WITH PAPILLARY THYROID CANCER IN VIETNAM NATIONAL CANCER HOSPITAL}

Introduction: Transoral endoscopic thyroidectomy vestibular approach (TOETVA) is a novel remote-access endoscopic approach. This method has applied in treating thyroid cancer worldwide. Patients and Methods: From May 2020 to May 2021, we performed 30 transoral endoscopic thyroidectomies via the vestibular approach for papillary thyroid cancer. Clinical features and outcomes were analyzed from a prospectively maintained database.Results: The average age was $29,3 \pm 7,4$ years. All patients were female. A tumor located in the right lobe accounted for $56,7 \%$ and in the left lobe contribute to $43,3 \%$. 26 patients underwent hemithyroidectomy, ismuthectomy plus unilateral central neck dissection with 105,5 minutes for the mean operative time. While 4 patients had total thyroidectomy plus bilateral central neck dissection with 140,5 minutes for the mean operative time. The rate of complications was very low. All patients were highly satisfied with the surgical outcome, especially, cosmetic results. Conclusion: The TOETVA for treating papillary thyroid cancer is a safe and effective procedure. For selected patients, this technique is a viable alternative to conventional thyroidectomy. 